\title{
Examining Perceived Risk and Its Influence on Attitudes: A Study on Private Label Consumers in Turkey
}

\author{
Yusuf Arslan ${ }^{1}$, Fatih Geçti ${ }^{2} \&$ Hayrettin Zengin ${ }^{1}$ \\ ${ }^{1}$ Faculty of Business, Sakarya University, Turkey \\ ${ }^{2}$ Faculty of Economics and Administrative Sciences, Yalova University, Turkey \\ Correspondence: Fatih Geçti, Department of Management, Faculty of Economics and Administrative Sciences, \\ Yalova University, Safran Campus, 77100, Yalova, Turkey. E-mail: fgecti@yalova.edu.tr
}

Received: March 6, $2013 \quad$ Accepted: March 22, $2013 \quad$ Online Published: March 28, 2013
doi:10.5539/ass.v9n4p158
URL: http://dx.doi.org/10.5539/ass.v9n4p158

\begin{abstract}
This study aims to examine perceived risk and its impact on consumers' attitudes towards private label brands. In order to achieve this aim, a field research was conducted on private label consumers in Turkey. 413 consumers attended the survey. According to the findings, the dimensions of the perceived risk towards private labels were determined as "financial risk", "physical risk", and "social risk". The perceived risk consisting of these dimensions has a negative influence on the attitudes towards private labels. In addition, negative correlations were found between each risk dimension and attitudes.
\end{abstract}

Keywords: perceived risk, private labels, consumer attitudes, Turkish consumers

\section{Introduction}

Private labels are the brands that are created and controlled by retailers (Sayman et al., 2002) and where the retailers have the sole responsibility from development, purchase, and storage to marketing (Dhar \& Hoch, 1997). In addition to changing economic and social environmental conditions, diversifying consumer attitudes and behaviors, nationally and internationally increased competition among retailers played a significant role in the development process of such brands. Thus, retailers' brands have started to follow a dynamic structure in order to adapt themselves to ever-developing environmental conditions (Schneider, 2004).

The market share of the private label sector, which has reached 250 billion $\$$ throughout the world, has reached 2.5 billion $\$$ in Turkey. With its manufacturing quality and rate, Turkey has surpassed China, which is the biggest rival of Turkey in this field. Chinese producers can neither produce at desired quality nor deliver orders on time. In the present case, demand in the private label sector has shifted to Turkey (Akyüz, 2012:9).

Consumers' buying behaviors are considerably influenced by the risks perceived by them towards purchased products. Here-mentioned risks are the fear of the failure by the products in question to meet expected physical properties or the avoidance of getting a social reaction after buying the product in question (Dick et al., 1995). Different quality levels of private label products increase the risk perceived towards the product line in question. It is stated that consumers who do not want to take a risk prefer buying more expensive products so as to reduce buying a poor-quality product (Burton et al., 1998). Risks that consumers encounter during purchase may develop negative attitudes towards retailers' private labels. For example, product performance may be deemed insufficient. Product may be disapproved by the social circle of consumer or there may be an uncertainty on product performance in the market. Some consumers believe that private labels are poor-quality and that buying these brands is a loss of money (Dick et al., 1995).

In this regard, in the current study, perceived risk and its impact on consumers' attitudes towards private label brands are examined. In what follows, we begin by explaining perceived risk and its dimensions. We provide a brief literature review on consumers' attitudes towards private labels. We present the methods, measures and the analyses. Finally, we discuss the results in terms of their implications.

\section{Theoretical Framework}

\subsection{Perceived Risk}

Perceived risk can be explained as consumers' doubt on the results of their buying decisions. The degree of 
consumers' risk perception is one of the important factors influencing buying decision (Schiffman \& Kanuk, 2010).

The recognized types of perceived risks are as follows (Beneke et al, 2012:5-6; Demir, 2011:268):

1) Financial Risk: The possibility of a monetary loss from a poor purchase choice or losing money by purchasing an inadequate or unfamiliar brand. Financial risk also includes the risk that the product's quality does not match its price or that it is overpriced and available at a cheaper price elsewhere. Each buying is a contract bearing financial results. Financial liabilities accepted by consumers upon purchase of a product lead to financial risk. Besides, it is expected that the more expensive a product is, the bigger financial risk is.

2) Social Risk: A possible perceived loss of image or status through the purchase of a particular brand or product. Since social risk takes into account how society influences a consumer's decision, it becomes an important element of perceived risk

3) Physical Risk: The possibility that the product may harm the consumer and others in a physical sense-in other words, a consumer's fear that certain products can damage their health or physically injure their person. All health-related and physical concerns with regard to the use of a product are included in this risk group.

4) Functional Risk (Performance Risk): The uncertainty that the outcome of a product purchase will not meet consumer expectations. Functional risk is also expressed as a performance risk as it demonstrates the consumer's fear that a product will not perform to its promised abilities. The risk related to failure by product to meet expected performance. The doubt by consumer on benefit from a product causes a risk perceived by consumer. If a product is purchased for the first time, there is no information about the product, or use of the product requires expertise, functional risk is expected to increase.

5) Psychological Risk: A consumer's disappointment in making a poor product or service selection. Psychological risk is a concern related to consumer's discontent with owning or using the product.

\subsection{Attitudes towards Private Labels}

Attitude is a complex mental state involving our knowledge, experience, feelings, values, and tendencies to particular conditions. More specifically, attitude is to develop a new tendency to be able to respond consistently and predictably to a stimulant (Evans et al., 2010:106).

There are various studies on consumers' attitudes towards private labels. According to the classification by Baltas (1997), the studies on attitudes towards retailers' labels are collected under three groups. These groups are respectively made up of the studies on relations between retailers' labels and market variables, studies on consumers' perceptions towards retailers' labels, and the studies on introduction of consumer characteristics influencing retailers' label trends.

Guerrero et al. (2000) researched on consumers' attitudes towards private labels and suggested that national brands are perceived as more quality in terms of quality image although private labels are considered reliable. In his study, Hoch (1996) suggested that consumers being sensitive to prices buy private labels more. Sinha \& Batra (1999) suggested that the price - quality association perceived in risky product categories has significant impacts on the purchase of private labels.

Offering private labels at affordable prices and quality may ensure that they are preferred by consumers more, and may change consumers' attitudes towards private labels. At this point, introduction of risks perceived by consumers towards private labels and efforts by retailers to reduce those risks will play a significant role in positively affecting attitudes towards private labels (Kılıç \& Altıntaş, 2010:119).

\section{Method}

\subsection{Purpose and Hypothesis of the Study}

The main objective of this study is to present the relation between perceived risk and consumers' attitudes towards private labels by examining the risk perceived towards private labels. In this study, the perceived risk concept was addressed under five sub-dimensions. These dimensions are financial risk, social risk, performance risk, physical risk and psychological risk. In this regard, it is another objective of this study to determine how valid and reliable these dimensions are in terms of private labels and to reveal to what extent these dimensions represent the perceived risk concept.

In this regard, the research question we need to answer is as follows:

$\checkmark \quad$ To what extent the dimensions of perceived risk explain perceived risk?

When the relevant literature is examined, it is seen that there are studies related to the influences of consumers' 
risk perceptions on private labels. Mieres et al. (2006), suggested that financial risk has a significant impact on consumers' buying decisions of private labels. Besides, private labels were stated to be more risky product categories than national brands in terms of performance risk due to uncertainty in their possible functional performance.

Baltas (1997) concluded that private labels are more risky than national labels in terms of negatively affecting social status of consumers. Kwon et al. (2008) introduced that the uncertainties in buying a new product cause consumers' exposure to a kind of emotional and psychological pressure because private labels are relatively newer alternatives than national brands. Dick et al. (1995), mentioned that there is a considerable difference between consumers having positive attitudes and consumers having negative attitudes towards private labels.

In this regard, based on the above discussions and findings, the hypothesis was proposed as follows;

$\mathrm{H}_{1}$ : Consumers' perceived risk towards private label brands has a negative effect on their attitudes towards these brands.

\subsection{Sampling Process and Data Collection}

The population of the research includes all of the private label consumers in Turkey. Due to some restrictions such as time, cost and difficulty to reach all the population; the study was limited with the sample. Since there is no sample framework for the people who consume the private labels, the convenience sampling method was used. Data were collected through an online survey. 413 consumers participated in the survey which was open for two months on the relevant web page.

\subsection{Measures}

The measure of the dimensions of perceived risk was adapted from the studies of Akturan (2007), Yaraş et al, (2009) and Demir, (2011). To measure the attitudes towards private labels, we applied the scale from Burton et al. (1998). 5-point Likert type scale ranging from 1- (Strongly Disagree) to 5- (Strongly Agree) was attached to each statement.

\subsection{Analysis Method}

Proposed relationships were tested using structural equation modeling via AMOS.

\section{Analysis and Results}

\subsection{Participant Profile}

Demographic features of the participants are displayed in Table 1.

Table 1. Demographic features of the participants $(n=413)$

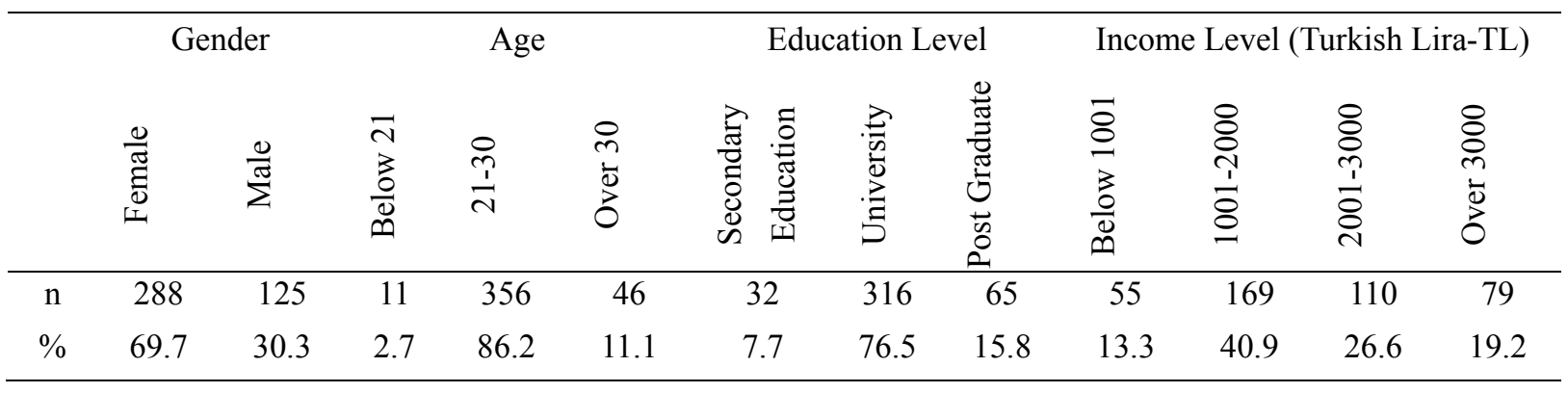

According to the Table 1, most of the participants were female (0.69), were under 30 years old $(0.88)$, had university degree (0.76) and had up to 2000 TL monthly income (0.54).

\subsection{Measurement Model}

First order confirmatory factor analysis was conducted in order to be able to learn validity and reliability of the scales (financial risk, physical risk, social risk, psychological risk, performance risk, and attitude), and internal consistency of each factor was calculated.

Confirmatory factor analysis loads for psychological risk scale were below 0.50 and Cronbach's alpha value was 0.53. Confirmatory factor analysis loads for performance risk scale were also below 0.50 and Cronbach's alpha value was 0.42 . Most researchers stated that reliability-related critical values must be at least 0.60 and the values below that value are unacceptable (Clark \& Watson, 1995; Muller, 2009; Chaichi, 2012). 
In this regard, psychological risk and performance risk was removed from the analysis since no valid and reliable results of these factors could be obtained, and the measurement model was analyzed in terms of other factors.

Findings for measurement model are given in Table 2.

Table 2. Scale items, first-order and second order measurement model: Cfa results

\begin{tabular}{lcc}
\hline & First-Order Model & Second-Order Model \\
Scale/Items & Factor & Factor \\
& Loading & Loading
\end{tabular}

Financial Risk (C.R. $=0.75, \mathrm{AVE}=0.48, \alpha=0.73)$

FI1- (I think buying a private label brand does not imply a waste of my money)

FI2- (If I buy a private label brand, I like to be sure that I get the best value for the money I spend)

FI3- (Buying a private label brand refers to smart shopping)

Social Risk (C.R. $=0.88, \mathrm{AVE}=0.71, \alpha=0.87)$

SO1-(I think buying private label brand gives me prestige)

SO2- (People's opinions on me are positively affected when I buy a private label brand)

SO3- (If I buy a private label brand, I like to be sure that I 0.89 receive positive criticism from the people I value their opinions)

Physical Risk (C.R. $=0.82$, AVE $=0.60, \alpha=0.81)$

PH1 - ( I think private label brands are reliable)

$0.82 \quad 0.87$

PH2- (I believe private label brands do not have detrimental effects on health)

$0.66 \quad 0.63$

PH3- (I think private label brands are healthy)

0.85

Structural Parameters of the Second Order Model

Perceived Risk $\longrightarrow$ Financial Risk 0.88

$\begin{array}{ll}\text { Perceived Risk } \longrightarrow \text { Social Risk } & 0.49\end{array}$

Perceived Risk $\longrightarrow$ Physical Risk 0.98

Model Fit Statistics

$\begin{array}{ll}\text { Chi-square }\left(\chi^{2}\right)=66.458 & \text { Chi-square }\left(\chi^{2}\right)=66.458 \\ \text { Df }=24 & \text { Df }=24 \\ \chi^{2} / \mathrm{df}=2.76 & \chi^{2} / \mathrm{df}=2.76 \\ \text { GFI }=0.97 & \text { GFI }=0.97 \\ \text { AGFI }=0.94 & \text { AGFI }=0.94 \\ \text { TLI }=0.96 & \text { TLI }=0.96 \\ \text { CFI }=0.98 & \text { CFI }=0.98 \\ \text { RMSEA }=0.066 & \text { RMSEA }=0.066\end{array}$

Attitude (C.R. $=0.84, \mathrm{AVE}=0.76, \alpha=0.83$ )

AT1- (For most product categories, the best buy is usually the private label brand)

\subsection{5}


AT3-(Considering value for the money, I prefer private label brands to national brands)

AT4-(When I buy a private label brand, I always feel that I am getting a good deal)

Model Fit Statistics
0.83

0.87

Chi-square $(\chi 2)=4.516$

$\mathrm{Df}=2$

$\chi^{2} / \mathrm{df}=2.26$

$\mathrm{GFI}=0.99$

AGFI $=0.97$

$\mathrm{TLI}=0.99$

$\mathrm{CFI}=0.97$

RMSEA $=0.055$

Factor loadings ranged from 0.70 and 0.76 for financial risk, 0.70 and 0.92 for social risk, 0.66 and 0.82 for physical risk. Composite reliabilities for the measurement scales ranged from 0.75 and 0.88 . All of the constructs but financial risk (0.48) had AVE estimates greater than 0.50. Cronbach's alpha coefficients for the measures ranged from 0.73 and 0.87 . When fit statistics for these three sub-factors are examined, it is seen that model provides good fit $\left(\right.$ Chi-square $=66.458$; Degrees of freedom $=24 ;{ }^{2} / \mathrm{df}=2.76 ;$ GFI $=0.97 ;$ AGFI $=0.94 ;$ TLI $=$ 0.96; CFI $=0.98$; RMSEA $=0.066$ ). As both the fit indices and item loads of each factor are within the acceptable levels $(>.65)$; it can be said that convergent validity is ensured for the dimensions of perceived risk.

Second order confirmatory factor analysis was applied in order to be able to learn to what extent sub-dimensions of perceived risk explain the concept. Results suggested that physical risk is the most reliable indicator (0.98) followed by financial risk (0.88) and social risk (0.49) dimensions.

In addition, confirmatory factor analysis loads of attitude, which is the endogenous variable, ranged from .65 and .87 . Composite reliability (CR) value of the factor was 0.84; Average variance extracted (AVE) value was 0.76, and Cronbach alpha value was 0.89. The measurement model for attitude provided good fit statistics $\left(\right.$ Chi-square $=4.516 ;$ Degrees of freedom $=2 ;{ }^{2} / \mathrm{df}=2.26 ; \mathrm{GFI}=0.99 ; \mathrm{AGFI}=0.97 ; \mathrm{TLI}=0.99 ; \mathrm{CFI}=0.97$; RMSEA $=0.055)$.

Discriminant validity was used in order to test whether the variables (financial risk, social risk, physical risk and attitude) in the measurement model were really different from each other. Discriminant validity was tested by using Chi-square differences between Model 1, where correlations fixed at 1, and Model 2, where correlations were free (Bagozzi et al, 1991).

The results of discriminant validity are given in Table 3 .

Table 3. Result of discriminant validity

\begin{tabular}{lcc}
\hline Models & Chi-square & Degree of freedom \\
\hline Model 1 (Correlations fixed at 1) & 800.836 & 65 \\
Model 2 (Correlations free) & 132.223 & 59 \\
$\Delta$ Chi-square & 668.613 & 6 \\
$\Delta$ Degree of freedom & & 6 \\
\hline
\end{tabular}

Discriminant validity is provided whether the chi-square value of the unconstrained (free) model was significantly lower than the fixed one. According to $\chi 2$ distribution table, the critical value of 6 degrees of freedom is 12.592 . Therefore, the critical value $(\chi 2(6)>12.592)$ indicates that discriminant validity was upheld.

Correlations among the constructs in the model are shown in Table 4. 
Table 4. Correlations among constructs

\begin{tabular}{lcccc}
\hline Constructs & 1 & 2 & & 3 \\
\hline 1- Financial Risk & 1.00 & & & \\
2- Social Risk & 0.43 & & 1.00 & \\
3- Physical Risk & 0.86 & 0.47 & 1.00 & 1.00 \\
4- Attitudes & -0.82 & -0.50 & -0.77 & \\
\hline
\end{tabular}

According to the Table 4, correlation values between the structures in the model ranged from -0.82 and 0.86 .

\subsection{Structural Model and Hypothesis Test}

In order to test the hypothesis of the research; structural equation modelling was used. Structural model is shown in Figure 1.

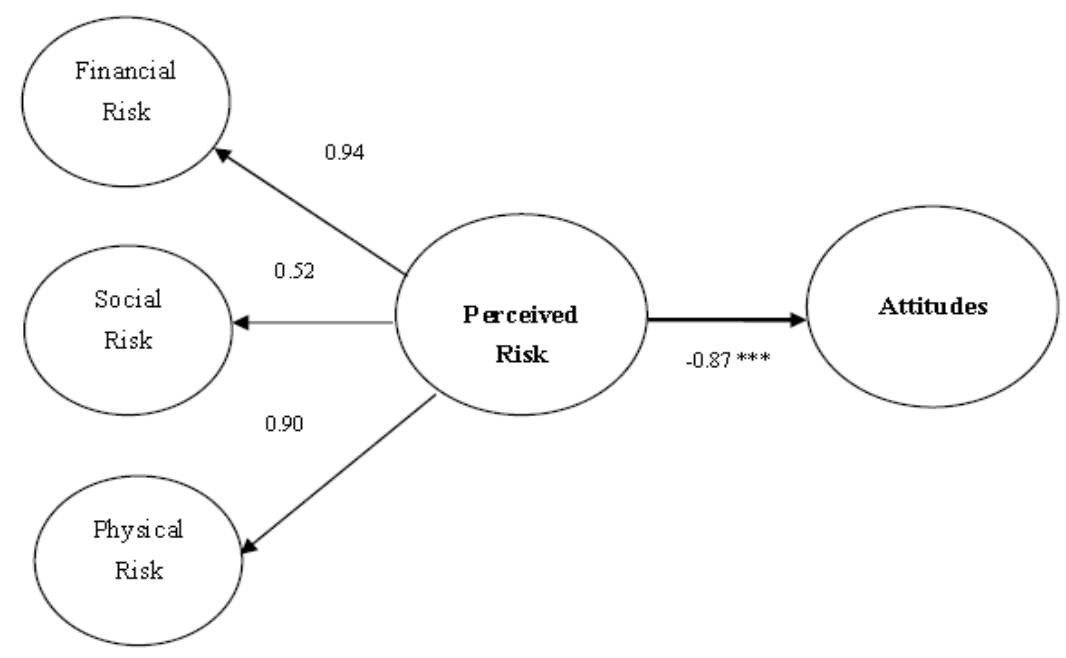

Figure 1. Structural model

Note. $* * * \mathrm{p}<.001$

The structural model provided good fit $\left({ }^{2} / \mathrm{df}=2.30 ; \mathrm{GFI}=0.95 ; \mathrm{AGFI}=0.93 ; \mathrm{TLI}=0.96 ; \mathrm{CFI}=0.97\right.$; RMSEA= $0.05)$. Result of the hypothesis test is displayed in Table 5

Table 5. Result of hypothesis testing

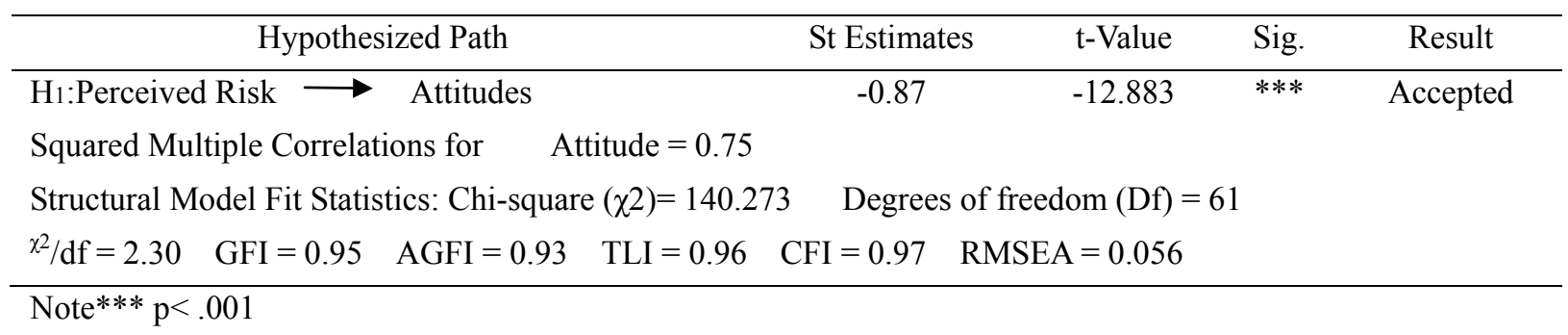

According to Table 5, the hypothesis $\left(\mathrm{H}_{1}\right)$, which consumers' perceived risk towards private label brands has a negative effect on their attitude towards these brands, was accepted $(\beta=-0.87 ; \mathrm{t}=-12.883 ; \mathrm{p}<0.001)$.

\section{Conclusions and Discussion}

In the current study, perceived risk towards private label brands was examined from the dimensional aspect and the influence of perceived risk on the attitudes to these brands was analyzed. In the literature, perceived risk 
generally consists of financial risk, physical risk, social risk, performance (functional) risk and psychological risk dimensions. Primarily, in this study, to what extent these dimensions can explain consumers' perceived risk towards private labels was presented. In this context, performance (functional) risk and psychological risk were removed from the analysis, because they could not provide valid and reliable results.

Contrary to expectations, perceived risk consisted of three dimensions. There may be various reasons why perceived risk was only explained by these dimensions. Firstly, this research was conducted in Turkey. As it is known, Switzerland is the country which has the highest market share (54\%) in the private label market. In Germany, Belgium, England, and Spain, the total share of private label brands is about $40 \%$. For Turkey, although it has a low share as $13 \%$, it has a growing trend. Private label brands are primarily perceived as food and cleaning products in Turkey, where the research was carried out, as in all around the world. As well as private labels were there in the retail industry before 2001, essential growing corresponded to post-economic crisis period which took place in 2001. Due to the economic crisis, which resulted in the most serious recession, the demand for private labels increased in Turkey. After that crisis, consumers preferred private label brands more than before. Being effective of economic crisis to increase in market share of private labels in Turkey caused comprising various perceptions towards to aforesaid products in the aspects of quality, price, packaging etc.

Psychological risk arises from concerns of consumer about being dissatisfied for using the product. It includes an expectation level within the satisfaction concept. After the crisis, private labels positioned in the market with low-price perceptions have low-expectation level because of that positioning. It is considered that the low expectation level prevents emerging of psychological risk.

Performance risk is explained as tension arising from the case of being unsure of customer about the benefits gained from the product and it is mostly a matter of new and technologically sophisticated products. Financial risk becomes prominent for the products which are believed to there is no difference between different brands for In current research for not being able to determine performance risk, it is accepted that private label brands are products such as food and cleaning products and benefits acquired by consumers about the given product group is more apparent in comparison with other products.

According to the result of second-order confirmatory factor analysis, physical risk is the most reliable indicator that represents perceived risk (0.98). Respectively, financial risk (0.88) and social risk (0.49) follow it. Being best indicator of physical risk for stating the possibility of physical harm for user of the product is parallel with the related literature. For example, physical risk here is a health concern for butter whereas it is both physical harm possibility for both user and other materials that product implemented on it for detergent. For private labels, having a high proportion in the food and cleaning products is effective for getting high physical risk perception.

Within the structural equation modeling framework, it is revealed that perceived risk towards private labels has a significant and negative effect $(-0.87)$ on attitudes towards these brands. Thus, proposed hypothesis was accepted. Moreover, negative correlations between each dimension consisting perceived risk and attitudes to these brands were found.

Attitudes have a structure that acquired by learning and it may change in time. This change and development happen in the conclusion of learning and experimenting process. Consumers' positive or negative assessment process also affects their behavior. Since attitudes are gained by learning and that determine behaviors, it is possible to change the behaviors by changing the attitudes.

In Turkey, changing behaviors of consumers towards private labels should be started from changing and developing attitudes towards these brands. It is considered that the forming process of attitudes towards private labels corresponded to post-economic crisis period, has an effect on forming of attitude.

Minimizing the risk factor in the course of the generating attitude process shall affect the change in behaviors towards the product. In this context, this study is original because it contributed to the literature that which risk factor is more effective on generating attitudes towards private labels. In addition, it also gives information to practitioners about which risk factor should be considered in order to change behaviors.

\section{Limitations and Further Studies}

Data were collected via online survey. Similar to the other online surveys, the sample includes only the consumers who are willing to answer the questions in the survey and this causes an important limitation. In addition, it is impossible to say that sample can represent entire universe. Therefore, the results cannot be generalized. Moreover, due to psychological cases of respondents and the circumstances they have in the course of responding the questionnaire is unknown, reliability of the answers may become questionable. Besides, as the 
data were characterized as cross-sectional, changing consumer perceptions towards brands were ignored.

Upon this research, fruitful avenues might be explored for further studies. The current research was conducted as including all private label brands and there was no categorical separation among them. However, consumers' perceived risks may vary accordingly with product categories. In this regard, in further studies, perceived risk may be examined in terms of different product categories. Moreover, in respect to different private label categories, consumers' attitudes towards these categories could be investigated. Because private labels have a wide range of scope and consumers' attitudes towards these brands may vary accordingly with product groups.

\section{References}

Akruran, U. (2007). Satın alma karar sürecinde markaya yönelik algılanan riskin algılanan değer üzerindeki etkisi, Yayımlanmamış doktora tezi, Sosyal Bilimler Enstitüsü, İstanbul Üniversitesi.

Akyüz, M. (2012). Private label sektöründe talep Türkiye’ye kayıyor. Plat-Özel Markalı Ürünler ve Tedarikçileri Dergisi, 1(4), 8-9. Retrieved from http://www.plturkey.org/basin/PLATSayi4.pdf

Bagozzi, R. P., Li, Y., \& Philips, L. W. (1991). Assessing construct validity in organizational research. Administrative Science Quarterly, 36(3), 421-458. http://dx.doi.org/10.2307/2393203

Baltas, G. (1997). Determinants of store brand choice: A behavioral analysis. Journal of Product \& Brand Management, 6(5), 315-324. http://dx.doi.org/10.1108/10610429710179480

Beneke, J., Greene, A., Lok, I., \& Mallett, K. (2012). The influence of perceived risk on purchase intent: the case of premium grocery private label brands in South Africa. Journal of Product \& Brand Management, 21 (1), 4-14. http://dx.doi.org/10.1108/10610421211203060

Burton, S., Lichtenstein, D. R., Netenmeyer, R. G., \& Garretson, J. A. (1998). A scale for measuring attitude toward private label products and an examination of its psychological and behavioral correlates. Journal of Academy of Marketing Science, 26(4), 293-306. http://dx.doi.org/10.1177/0092070398264003

Chaichi, K. (2012). Impact of staff training on customer satisfaction in travel agencies in Klang Valley Malaysia. European Journal of Social Sciences, 29(2), 270-282.

Clark, L. A., \& Watson, D. (1995). Constructing validity: Basic issues in objective scale development. Psychological Assessment, 7 (3), 309-319. http://dx.doi.org/10.1037/1040-3590.7.3.309

Demir, M. Ö. (2011). Risk algısının marka sadakatine etkisi: Cep telefonları kategorisinde bir uygulama. Ege Akademik Bakıs- Ege Academic Review, 11(2), 267-276

Dhar, S. K., \& Hoch, S. J. (1997). Why store brand penetration varies by retailer. Marketing Science, 16(3), 208-227. http://dx.doi.org/10.1287/mksc.16.3.208

Dick, A., Jain, A., \& Richardson, P. (1995). Correlates of store brand proneness: some empirical observations. Journal of Product \& Brand Management, 4(4), 15-22. http://dx.doi.org/10.1108/10610429510097663

Evans, M., Jamal, A., \& Foxall, G. (2010). Consumer behaviour (2nd ed.). John Wiley \& Sons Ltd., England.

Guerrero, L., Colomer, Y., Guárdia, M. D., Xicola, J., \& Clotet, R. (2000). Consumer attitude towards store brands, food quality and preference. Food Quality and Preference, 11(5), 387-395. http://dx.doi.org/10.1016/S0950-3293(00)00012-4

Hoch, S. J. (1996). How should national brands think about private labels. Sloan Management Review, 37(2), 89-101.

Kılıç, S., \& Altıntaş, H. (2010). Özel Markalı Ürünlerin Pazarlama Stratejileri. Sistem Yayıncılık. 1. Basım.

Kwon, K. N., Lee, M. H., \& Kwon, Y. J. (2008). Effect of perceived product characteristics on private brand purchase. Journal of Consumer Marketing, 25 (2), 105-114. http://dx.doi.org/10.1108/07363760810858846

Mieres, C. G., Martin, A. M. D., \& Gutie'Rrez, J. A. T. (2006). Influence of store brand perceived risk on store brand proneness. International Journal of Retail \& Distribution Management, 34(10), 761-772. http://dx.doi.org/10.1108/09590550610691347

Muller, R. S. (2009). The impact of employee engagement on the business success of Johnson controls Uitenhage. Unpublished Dissertation, NMMU Business School, Republic of South Africa.

Sayman, S., Hoch, S. J., \& Raju, J. S. (2002). Positioning of store brands. Marketing Science, 21(4), 378-397. http://dx.doi.org/10.1287/mksc.21.4.378.134

Schiffman, G. L., \& Kanuk, L. L. (2010). Consumer behavior (10th Ed.). Prentice Hall, New Jersey, USA. 
Schneider, G. K. (2004). Perakendeci markalarında satın alma davranışı. Türkiye Private Label \& Perakende Dergisi, Nisan-Mayıs, 16-25.

Sinha, I., \& Batra, R. (1999). The effect of consumer price consciousness on private label purchase. International Journal of Research in Marketing, 16(3), 237-251. http://dx.doi.org/10.1016/S0167-8116(99)00013-0

Yaraş, E., Yeniçeri, T., \& Zengin, Y. (2009). Mağaza markalı ürün satın alan tüketiciler ile satın almayan tüketiciler arasında algılanan risk bakımından farklılık olup olmadığının incelenmesine yönelik bir araştırma. Kocaeli Üniversitesi Sosyal Bilimler Enstitüsü Dergisi, 18(2), 198-217. 